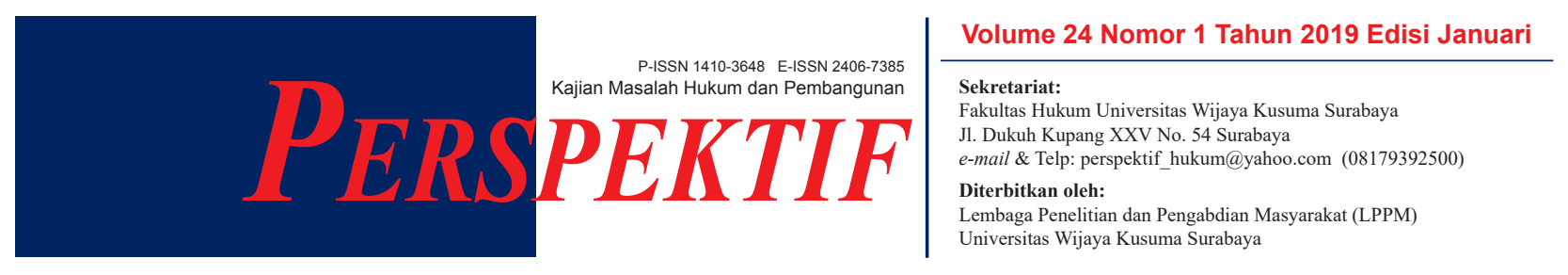

\title{
URGENSI BATASAN ATAU PENGENDALIAN ASAS KEBEBASAN BERKONTRAK PADA PERISTIWA PRE PROJECT SELLING
}

\author{
Fani Martiawan Kumara Putra \\ Fakultas Hukum Universitas Wijaya Kusuma Surabaya \\ e-mail: fanimartiawan@gmail.com
}

\begin{abstract}
ABSTRAK
Peristiwa perdata, sudah barang tentu terjadi lebih banyak daripada peristiwa pidana. Sementara itu peristiwa perdata yang paling banyak terjadi, itu sudah pasti adalah peristiwa perikatan. Perikatan cukup mendominasi karena dapat terjadi atas dasar antar subyek hukum saling mengikatkan dirinya, atau atas dasar antar subyek hukum dipaksa saling mengikatkan dirinya oleh undang-undang. Subyek hukum yang saling mengikatkan dirinya, menjadi peristiwa perikatan yang mendominasi di masyarakat, bentuknya adalah perjanjian. Perjanjian terdapat beragam jenisnya, yang pada intinya ada perjanjian bernama, ataupun perjanjian tidak bernama. Salah satu contoh perjanjian tidak bernama yang dewasa ini marak digunakan sebagai pendukung kegiatan bisnis, adalah perjanjian pre project selling, perjanjian di mana penjualan dilakukan saat obyek tersebut belum nyata ada. Perjanjian pre project selling ini kerapkali dilakukan dalam bidang penjualan properti. Kendati demikian, perjanjian semcam ini tidak selamanya berakhir dengan baik, berulang kali timbul kerugian kepada pembeli (calon pemilik) baik itu dalam bentuk obyeknya tidak kunjung jadi, ataupun dalam bentuk obyeknya sudah jadi namun tidak sesuai dengan kehendak pembeli (calon pemilik) sebagaimana dalam penawaran. Tujuan dari penulisan ini adalah untuk mencari penyebab kerugian tersebut, dan penyelesaiannya. Hasil dari penelitian ini, adalah dibutuhkan mekanisme pembatas atau pengendali atas asas kebebasan berkontrak dalam peristiwa pre project selling. Kata Kunci: batasan; kebebasan berkontrak; pre project selling
\end{abstract}

\section{ABSTRACT}

Civil events, of course, occur more than criminal events. While most civil incidents occur, it is definitely an engagement event. Engagement is quite dominating because it can occur on the basis of legal subjects binding to one another, or on the basis of legal subjects being forced to bind themselves to each other by law. Legal subjects that bind themselves to each other, become engagement events that dominate in society, the form is an agreement. There are various types of agreements, which basically have a named agreement, or an anonymous agreement. One example of an anonymous agreement that is currently widely used as a supporter of business activities, is the pre-project selling agreement, an agreement where sales are made when the object is not yet real. These pre-project selling agreements are often done in the field of property sales. Nevertheless, this kind of agreement does not always end well, repeatedly causing losses to the buyer (prospective owner) either in the form of the object not being finished, or in the form of the object is ready but not in accordance with the wishes of the buyer (prospective owner) as in the offer. The purpose of this paper is to find the cause of the loss, and its resolution. The results of this study, is the limiting or controlling mechanism for the principle of freedom of contract in the event of pre-project selling.

Keywords: limitation; freedom of contract; pre project selling 


\section{PENDAHULUAN}

Manusia pada dasarnya memiliki sifat kehidupan yang bercorak zoon politicon yang artinya manusia itu tidak dapat hidup sendiri, melainkan harus berinteraksi dengan orang lain. Selain itu, sosok diri manusia itu juga sebagai homo economicus, yaitu dalam hidupnya manusia selalu memperhitungkan untung dan rugi, yang mana untung dan rugi ini tidak hanya yang bersifat materiil, namun juga yang bersifat imateriil. Keberadaan ini mengartikan bahwa demi eksistensinya sebagai makhluk hidup, manusis akan selalu berusaha untuk memenuhi kebutuhannya. Sedangkan kebutuhan-kebutuhan hidup hanya akan dapat dipenuhi dengan jalan berinteraksi dengan anggota masyarakat lainnya. Pemenuhan ini sudah pasti dilakukan dengan perhitungan untung dan rugi, yang mana kegiatan yang menitikberatkan untung dan rugi ini pada hakekatnya adalah inti kegiatan bisnis yang pada ujungnya adalah timbul ikatan antara para pihak tersebut pada ranah keperdataan.

Ikatan dengan karakter seperti ini tidak lain dan tidak bukan harus berada di bawah suatu payung yang melindungi kedudukan para pihak yang mengikatkan dirinya tersebut, kedudukan dimaksud adalah kedudukan hukum, karena ikatan semacam ini, sangat kental dengan nuansa dan aspek hukumnya. Hukum yang dapat menjadi payung hukum untuk kegiatan interaksi ikat mengikat sesama subyek hukum ini telah disediakan oleh pembuat UndangUndang melalui Buku III Burgerlijk Wetboek yang berjudul Perikatan.

Mendasar pada Burgerlijk Wetboek (selanjutnya disebut BW), Pasal 1313 (1) BW, dapat diketahui bahwa suatu perjanjian adalah suatu peristiwa di mana seorang berjanji kepada orang lain, atau di mana dua orang atau lebih saling berjanji untuk melaksanakan suatu hal. Dari peristiwa tersebut timbul suatu hubungan antara dua orang atau lebih yang dinamakan perikatan. Dengan demikian, perjanjian merupakan sumber terpenting yang melahirkan perikatan. Selain dari perjanjian, perikatan juga dilahirkan dari undang-undang, dengan kata lain, terdapat perikatan yang dilahirkan dari memang dikehendaki oleh para pihaknya untuk saling terikat, dan adapula perikatan yang lahir karena para pihak dipaksa saling terikat oleh undangundang. Perikatan yang terjadi di masyarakat, lebih sering di dominasi dengan perikatan yang lahir dari perjanjian.

Perbedaan yang paling substansial dari kedua macam lahirnya perikatan tersebut adalah keberadaan hak dan sumber hukumnya. Manakala perikatan itu lahir dari perjanjian, artinya hak dari salah satu pihak itu seharusnya akan ada, namun tidak jadi ada, serta sumber hukum bagi mereka adalah perjanjian mereka (sebagaimana redaksi Pasal 1338 BW). Sedangkan untuk perikatan yang lahir dari undang-undang, hak dari salah satu pihak itu sudah ada, namun menjadi tidak ada, serta sumber hukum dari perikatan mereka adalah aturan perundang-undangan.

Sebagai contoh perikatan yang lahir dari perjanjian adalah perjanjian jual beli, atau perjanjian sewa menyewa, yang pada intinya dapat berupa perjanjian bernama ataupun tak bernama. Sedangkan perikatan yang lahir dari undang-undang sebagai contohnya adalah hubungan orangtua dan anak yang diatur dalam Undang-Undang No. 1 Tahun 1974 tentang Perkawinan, atau perbuatan melanggar hukum yang ditegaskan dalam Pasal 1365 BW.

Salah satu bentuk perikatan yang sedang marak adalah pada peristiwa Pre Project Selling. Pre Project Selling (selanjutnya disebut PPS) merupakan salah satu strategi pemasaran para pengembang, dengan tujuan utama yaitu pendapatan dana guna modal pembangunan dan keuntungan. Cara dari PPS ini adalah dengan penawaran unit hunian berdasarkan brosur yang berisi mengenai konsep hunian, rancang bangun, luas hunian, lokasi hunian, letak strategis hunian, dan lain sebagainya. Perlu diingat yang menjadi inti dari PPS ini adalah sebenar-benarnya bangunan atau hunian yang ditawarkan dalam brosur itu belum senyatanya terwujud, bahkan kerapkali belum dibangun, masih berupa tanah. ${ }^{1}$

Kendati terlihat menguntungkan pihak pengembang, akan tetapi tetap terdapat keuntungan bagi pembelinya (calon pemilik), yang mana merupakan daya tarik dari PPS itu sendiri, yaitu penawaran harga yang lebih murah dibandingkan manakala nanti saat hunian tersebut telah senyatanya terwujud atau jadi.

\footnotetext{
${ }^{1}$ Farid Husin. (2017). "Perjanjian Kerjasama Antara Pelaku Pembangunan Rumah Susun Dengan Bank Terhadap Penjualan Rumah Susun Melalui Sistem Pre Project Selling." Jurnal Spirit Pro Patria. Volume IV Nomor 1 Tahun 2017. Surabaya: Universitas Narotama Surabaya, h. 31.
} 
PPS ini pada akhirnya terjadi kesepakatan antara penjual (pengembang) dan pembeli (calon pemilik), kesepakatan dapat dibuat tertulis dan komprehensif, ataupun tertulis secara sederhana, melibatkan Notaris ataupun tidak, dan bahkan dapat dibuat dengan tidak tertulis (dalam arti tidak ada nota pembayaran dan/ atau surat keterangan pembayaran satupun, walau sudah dibayar oleh pembeli).

Pada perjanjian tertulis yang diikat dalam suatu PPS, sudah barang tentu klausulanya adalah bebas sebagaimana Pasal 1338 BW, asalkan tidak bertentangan dengan apa yang ditegaskan dalam Pasal 1320 BW. Pada bagian inilah permasalahan kerapkali terjadi, beragam sengketa muncul atas ketidaksesuaian hunian dengan brosur yang ditawarkan, kerapkali terjadi pula bahwa pihak pengembang mendalilkan klausula-klausula yang menguntungkan dirinya, baik itu tertulis tegas lalu disepakati oleh pihak pembeli (calon pemilik) atas dasar tergiur penawaran keuntungan-keuntungan yang dapat diperoleh, ataupun tidak tertulis namun dianggap sebagai bagian dari kesepakatan yang telah terjalin sebelumnya.

Potensial kerugian yang kerapkali terjadi pada peristiwa PPS ini mengerucut pada akibat dari tidak terbatasnya asas kebebasan berkontrak sebagaimana Pasal 1338 BW dalam praktik PPS, juga tidak adanya kewajiban keterlibatan seorang yang ahli (seperti Notaris) dalam praktik PPS.

\section{PERUMUSAN MASALAH}

Berdasarkan penjabaran di atas, maka permasalahan yang akan dikaji dalam penelitian ini adalah Urgensi Batasan atau Pengendalian Asas Kebebasan Berkontrak Pada Peristiwa Pre Project Selling.

\section{PEMBAHASAN}

Perjanjian atau persetujuan pada pengaturan norma dasarnya terletak pada Pasal 1313 BW, yang redaksinya menegaskan bahwa satu orang atau lebih saling mengikatkan dirinya. Kata 'persetujuan' merupakan terjemahan dari bahasa Belanda 'overeenkomst'.

Pada kalangan tertentu lebih suka menggunakan istilah kontrak. Beberapa akademisi ada pula yang mempersamakan antara kontrak dan perjanjian, dan ada pula yang membedakan keduanya. Cukup banyak argumentasi alasan mengapa perjanjian dan kontrak itu berbeda, namun beberapa dapat diambil intinya adalah kontrak bentuknya tertulis dan mempunyai kekuatan lebih mengikat. Penulis sendiri berpendapat bahwa kontrak dan perjanjian adalah tidak berbeda, hal ini mengingat keduanya berlandaskan atas kesepakatan, di mana ini dikenal dengan asas konsensuil yang tercermin melalui Pasal 1320 angka (1) BW. Asas ini menjadi panduan kapan perjanjian atau kontrak itu lahir. Mengenai tertulis atau tidak kekuatan mengikatnya sama, yaitu mengikat layaknya undang-undang bagi para pembuatnya, sebagaimana amanah yang ditegaskan dalam Pasal 1338 BW. Selanjutnya adalah judul BAB 2 Buku III BW, ditegaskan mengenai perikatan yang lahir dari kontrak atau persetujuan, mendasar pada redaksi ini, BW sebagai sumber Hukum Perdata di Indonesia menggunakan kata atau, artinya kontrak itu sama dengan persetujuan atau perjanjian.

Kendati demikian menurut penulis tetap ada batasannya, yaitu perjanjian adalah sama dengan kontrak, sepanjang perjanjian itu melahirkan perikatan. Mengingat perjanjian atau kontrak yang dibahas ini ada dalam ranah Buku III BW, sedangkan terdapat juga perjanjian yang tidak terdapat dalam Buku III BW, dan tidak mempunyai sifat obligatoir (yang artinya hanya salah satu pihak saja yang dibebani kewajiban), yaitu perjanjian jaminan kebendaan, yang mana diaturnya dalam Buku II BW. Artinya, perjanjian jaminan Gadai atau perjanjian jaminan Fidusia contohnya, itu tidaklah dapat disebut ataupun dipersamakan dengan kontrak jaminan Gadai atau kontrak jaminan Fidusia.

Pada suatu perjanjian, setidaknya terdapat 5 (lima) asas penting yang harus diperhatikan, antara lain: 1. Asas kebebasan berkontrak (freedom of contract); 2. Asas konsensualisme; 3. Asas kepastian hukum dalam perjanjian (pacta sunt servanda); 4 . Asas itikad baik; 5. Asas kepribadian (privity of contract).

Hal lain yang harus diperhatikan adalah unsur atau bagian dari perjanjian, yaitu: 1. Unsur Essentialia (harus ada karena keterkaitan dengan inti dari perjanjian); 2. Unsur Naturalia (tidak perlu diatur lebih lanjut oleh para pihak, karena dianggap telah diatur oleh undang-undang, tinggal mematuhinya); 3. Unsur Accidentalia (dikehendaki oleh para pihak, 
namun tidak diatur dalam undang-undang, jadi harus melalui kesepakatan para pihak).

Asas dan unsur atau bagian dalam perjanjian akan menentukan substansi perjanjian tersebut, namun satu hal yang menentukan substansi tersebut dapat diterima dalam konstelasi hukum di Indonesia, adalah harus melalui pengujian sah atau tidaknya perjanjian tersebut. Instrumen pengujinya adalah Pasal 1320 BW, di mana terdapat 4 (empat) syarat, yaitu: 1. Sepakat; 2. Cakap; 3. Obyek tertentu; 4. Kausa yang diperbolehkan.

Tidak memenuhi syarat pertama dan kedua, artinya melanggar syarat subyektif (berkaitan dengan subyeknya), oleh karena itu akibat hukumnya adalah dapat dibatalkan (vernietigbaar), sedangkan tidak dipenuhinya syarat ketiga dan keempat, mengakibatkan perjanjian tersebut batal demi hukum (nietig).

Pada suatu perjanjian PPS, baik itu asas, unsur atau bagian, dan syarat perjanjian, dapat dibuktikan dengan mudah bahwa semuanya telah terpenuhi, yang mana konsekuensinya adalah perjanjian tersebut sah, diterima dalam konstelasi hukum di Indonesia, bersifat pribadi, dan dapat dimintakan bantuan pengadilan untuk pemenuhannya.

Poin terakhir, yaitu bantuan pengadilan untuk pemenuhannya ini merupakan keistimewaan suatu perikatan, baik itu perikatan yang lahir dari undangundang ataupun yang lahir dari Perjanjian. Termasuk pula perjanjian PPS. Kendati demikian agar berhasil itu batasannya, yaitu sepanjang pembuktian berhasil dilakukan di Pengadilan, hal ini susah dilakukan mengingat sejak awal perjanjian, pembeli (calon pemilik) itu ditawarkan hanya melalui brosur, leaflet dan semacamnya, yang mana untuk realisasinya kerapkali tidak sesuai dengan penawaran.

Hal ini sebenarnya wajar, mengingat untuk merealisasikan bangunan yang sama persis dengan brosur sepatutnya memang sangat susah, namun yang tidak wajar adalah cela ini digunakan beberapa developer untuk menarik perhatian pembeli (calon pemilik) hingga mau mengeluarkan dana, dan klausula perjanjian sangatlah minim, sehingga pihak developer dapat menentukan klausula-kalusula sendiri yang dianggap disetujui oleh pihak pembeli (calon pemilik) saat tertarik penawaran hingga membayarkan sejumlah harga.
Pelaksanaannya di Indonesia dilakukan penyesuaian sehingga ada pengembang proyek yang melaksanakan PPS sebelum prasarana dan sarana dibangun, tetapi ada juga yang memasarkan setelah sarana dan prasarana tersebut telah dibangun. ${ }^{2}$ Beragam perkara bermunculan mengenai perjanjian PPS sebagaimana di atas, mulai dari perkara bangunan telah jadi, hingga bangunan tidak dibangun dan diproses secara pidana, seperti saat penelitian ini ditulis, suatu perkara Perumahan The Mustika Garden yang ditawarkan melalui brosur dengan metode penjualan PPS, tidak jadi dibangun. Titik berat anggapan penulis itu tidak pada aspek pidananya, namun sejatinya jual beli menggunakan metode semacam ini dapat berlangsung dengan baik, manakala prinsip kehati-hatian lebih diperhatikan. Mengingat, manakala ditelusuri secara vertikal, halhal ini karena adanya asas kebebasan berkontrak.

\section{Pembeli Dalam Pre Project Selling}

Sebelum membahas lebih lanjut mengenai asas kebebasan berkontrak, perlu dipertegas mengenai konsep pembeli dalam PPS. Mengingat terdapat beberapa mekanisme pembayaran, baik itu yang langsung dilunasi, dan sebagian besar melalui uang tanda jadi terlebih dahulu dengan jumlah yang telah ditentukan pada saat penawaran, dan juga obyek yang belum ada.

Telah disampaikan penulis di atas, bahwa pada perjanjian PPS, memenuhi syarat sah perjanjian akan sangat mudah. Padahal manakala diperhatikan, terdapat syarat mengenai obyek tertentu, artinya adalah harus ada obyeknya. Sementara pada PPS obyek tersebut belum ada. Pembuat BW pada masa lalu telah terbukti memikirkan perkembangan bisnis yang akan ada di masa mendatang, usia BW yang saat ini 181 (seratus delapan puluh satu) tahun, ternyata masih menjadi kunci keberhasilan dalam PPS, yaitu melalui Pasal 1334 BW, yang redaksinya menegaskan bahwa benda yang masih akan ada itu dapat dijadikan objek perjanjian. Ini sekaligus menunjukkan bahwa hukum yang dibutuhkan adalah hukum yang luwes saat melayani dunia bisnis yang senantiasa cepat berubah.

${ }^{2}$ Purbandari. (2012). "Kepastian dan Perlindungan Hukum Pada Pemasaran Properti Dengan Sistem Pre Project Selling." Jurnal Widya. Tahun 29 Nomor 320 Mei 2012. Jakarta: Kopertis Wilayah 3, h. 13. 
Obyek perjanjian dalam hal ini pada dasarnya adalah yang memiliki nilai ekonomis dan dapat dipindahtangankan (dialihkan kepemilikannya). Artinya, syarat obyek tertentu dalam Pasal 1320 BW pada peristiwa PPS memang bukanlah suatu masalah.

Perjanjian PPS karena tidak diatur khusus oleh BW, maka merupakan perjanjian tidak bernama, hal ini sebagaimana yang ditegaskan dalam Pasal 1319 BW yang redaksinya adalah manakala perjanjian itu tidak terkenal dengan suatu nama tertentu, maka tetap tunduk pada ketentuan-ketentuan umum. Lagilagi ini merupakan bentuk hasil pemikiran panjang pembuat BW untuk memfasilitasi kegiatan bisnis yang semakin hari semakin berkembang, pembuat BW telah dapat menerka, nantinya akan luar biasa beragam perjanjian yang tidak dapat disebutkan satu persatu dalam BW.

Walaupun sebagai perjanjian tak bernama, namun unsur atau bagian dari perjanjian yang telah disebutkan di atas, itu tetap harus dipenuhi. Mengingat hakekat dari PPS ini adalah jual beli, maka perlu diperhatikan keberadaan Pasal 1458 BW yang menegaskan bahwa jual beli dianggap telah terjadi antara kedua belah pihak, segera setelah tercapai kesepakatan tentang barang tersebut dan harganya, meskipun barang itu belum diserahkan dan harganya belum dibayar.

Pada peristiwa jual beli maka para pihaknya dinamakan penjual dan pembeli, oleh karena itu atas hal di atas, maka dalam PPS walaupun dibayar lunas ataupun dibayar angsuran dengan tanda jadi sejumlah dana yang ditentukan saat penawaran, pihak calon pemilik dalam hal ini disebut pembeli.

\section{Eksistensi Asas Kebebasan Berkontrak Pada Pre Project Selling}

Asas kebebasan berkontrak sebagaimana dalam tulisan ini menjadi suatu sebab permasalahan PPS, pengaturan dalam Pasal $1338 \mathrm{BW}$ ini merupakan sendi hakiki dari perjanjian, pasal ini menegaskan bahwa bahwa tiap-tiap perjanjian yang dibuat secara sah, mempunyai kekuatan mengikat sama dengan undang-undang bagi para pihaknya.

Tidak ditegaskan dalam pasal ini bahwa para pihak diberi kebebasan dalam menentukan apapun isi perjanjian, namun yang sebenarnya disampaikan dalam pasal ini adalah asalkan perjanjian sah, maka mempunyai kekuatan mengikat layaknya undang- undang, dan itu adalah salah satu ketentuan umum perjanjian sebagaimana di atas telah dijabarkan.

Selanjutnya yaitu melalui Pasal 1319 BW, di mana redaksinya adalah adanya pembedaan perjanjian bernama dan tidak bernama. Pesan penting yang dibawa oleh pembuat undang-undang pada ketentuan ini adalah tidak akan bertahan lama suatu ritme bisnis dalam suatu tatanan masyarakat, karena sudah pasti berubah-ubah seiring cepatnya perkembangan bisnis, oleh karenanya diikuti dengan tidak mampunya terpilih salah satu perjanjian bernama yang diatur dalam BW untuk digunakan sebagai bingkai bisnisnya para pelaku usaha.

Perkembangan dunia bisnis menuntut untuk lebih banyak varian bingkai hukumnya. Oleh karena itu bentuk kebebasan berkontrak seperti inilah yang yang dibawa oleh Pasal 1319 BW. Para pelaku usaha dipersilahkan membingkai bisnisnya sendiri dengan variabel dan aturan-aturan yang dikehendaki dan disepakati, dengan poin penting yaitu walau bebas saat membuat perjanjian bernama ataupun tak bernama, diwajibkan memperhatikan ketentuanketentuan umum yang berlaku.

Pada intinya, asas kebebasan berkontrak ini memiliki satu tujuan mulia yang senada dengan esensi BW, yaitu demi perkembangan dan kelancaran bisnis. Pada praktiknya oleh para pelaku usaha telah dipersiapkan rancangan perjanjiannya untuk ditawarkan pada pihak lain, demi efisiensi waktu dan cepat terwujudnya kesepakatan. Kendati demikian, perlu diingat bahwa dalam suatu perjanjian akan sangat susah untuk para pihaknya mempunyai posisi tawar (bargaining position) yang sama, tentunya ada satu yang sedikit lebih tinggi, termasuk pula dalam hal rancangan perjanjian yang dipersiapkan terlebih dahulu demi efisiensi, kedudukan para pihaknya sudah hampir dapat dipastikan sangat berat sebelah, karena kepentingan pembuat perjanjian akan lebih diutamakan daripada perlindungan hukum bagi pihak lawannya. Berbeda halnya manakala para pihak sama-sama saling berdiskusi, hingga menghasilkan kehendak dan kesepakatan yang sama untuk klausulaklausula dalam perjanjiannya, hal ini sebenarnya yang lebih diharapkan oleh hukum.

Keberadaan hal yang telah dijabarkan di atas itu dimanfaatkan oleh para pengusaha PPS dengan membuat perjanjian baku agar cepat 
terjadi kesepakatan yang adakalanya karena terlalu bebasnya, hingga merugikan pembeli (calon pemilik).

\section{Mekanisme Batasan Asas Kebebasan Berkontrak Pada Peristiwa Pre Project Selling}

Asas kebebasan berkontrak yang sebegitu istimewanya dan berperan penting dalam berhasilnya perjanjian PPS ini, sudah barang tentu tidak dapat dihilangkan, dan manakala dibatasi pun akan dinilai menimbulkan kerugian. Oleh karena itu dibutuhkan mekanisme pembatasan atau pengendalian asas kebebasan berkontrak ini yang mana saat itu dipahami dan sinergis dengan itikad baik, tidak akan ada pihak yang merasa dirugikan, sekalipun dalam mengejar efisiensi dan tuntutan cepatnya laju perkembangan bisnis.

Asas kebebasan berkontrak hanya ditandai dengan keinginan kcnsumen untuk menandatangani atau tidak menandatangani kontrak yang telah disediakan oleh pihak perusahaan pembiayaan konsumen, atau dengan kata lain take it or leave it. ${ }^{3}$ Agar tidak digunakan untuk menindas oleh pihak yang mempunyai daya tawar (bargaining power) tinggi, maka perlu adanya pengendali, semata-mata agar fungsi hukum tetap berorientasi pada keadilan, dan agar sifatnya tidak mendominasi lalu membuat prinsip yang ada di Pasal yang sama (1338 BW) contohnya Itikad baik, jadi tidak nampak. Salah satu caranya adalah mensinergikan prinsip-prinsip yang ada dalam aturan dasar asas kebebasan berkontrak tersebut, dan dalam peristiwa PPS adalah dengan instrumen perjanjian yang dibakukan oleh pemerintah. Pembakuan bentuk perjanjian ini tidaklah suatu hal yang aneh, karena semata-mata tujuannya adalah mengendalikan atau membatasi pemanfaatan asas kebebasan berkontrak yang keterlaluan, dan lagi-lagi demi memfasilitasi bisnis yang terus berkembang. Hal semcam ini sudah terbukti ampuh, contohnya saja pada lembaga jaminan yang sangat banyak diminati, yaitu Hak Tanggungan. Pada lembaga jaminan tersebut ditegaskan bahwa dalam Akta Pemberian Hak Tanggungan (APHT) itu diwajibkan adanya klausula-klausula tertentu, kalusula ini yang membatasi dan mengendalikan kebebasan berkontrak

\footnotetext{
${ }^{3}$ Dewi Hendrawati. (2011). "Penerapan Asas Kebebasan Berkontrak dalam Pembuatan Perjanjian Baku (Studi Normatif pada Perjanjian Pembiayaan Konsumen). Jurnal MasalahMasalah Hukum. Jilid 40 No. 4 Oktober 2011. Semarang: Universitas Diponegoro, h. 412.
}

para pihaknya. Contoh lainnya adalah lembaga jaminan Hipotek, pada lembaga jaminan ini tidak diwajibkan klausula-klausula tertentu seperti Hak Tanggungan, melainkan disediakan form yang baku, untuk perjanjian jaminan Hipoteknya, yang tentunya harus digunakan oleh para pihak.

Bukan hal yang aneh dan baru manakala ada batasan atau pengendalian dengan cara sebagaimana di atas, untuk peristiwa PPS ini pun dapat dilakukan demikian, baik itu pemerintah mengeluarkan satu undang-undang tersendiri, ataupun melalui instrumen lain yang harus dipatuhi oleh para pihak.

Pembuatan undang-undang sebagaimana di atas, sudah barang tentu bukanlah hal yang mudah, mengingat apa yang tertuang dalam undang-undang tersebut harus dipikirkan baik-baik guna tetap dapat digunakan jangka waktu panjang, dalam perannya memfasilitasi beragam kegiatan bisnis selama itu. Oleh karena itu diperlukan mekanisme lain yang dapat segera digunakan selagi menunggu undangundang semacam itu ada. Mekanisme yang dimaksud adalah dengan melibatkan seseorang yang dengan keilmuannya itu menjadi dibutuhkan oleh masyarakat dan mendapat amanah oleh undang-undang sebagai pejabat umum, yaitu Notaris.

Keterlibatan Notaris ini sifatnya adalah wajib. Demikian perjanjian PPS dapat dibuat oleh Notaris atau dihadapan Notaris. Melalui adanya peran Notaris ini, sudah barang tentu akan menekan tingginya angka kerugian yang disebabkan asas kebebasan berkontrak yang tak terkendali atau tak terbatas pada peristiwa PPS. Kendati demikian agar hal ini dapat diwujudkan, Pemerintah melalui kewenangannya harus mengeluarkan instrumen hukum yang mewajibkan keterlibatan Notaris dalam peristiwa PPS.

Mekanisme selanjutnya adalah sinergitas prinsip terkait asas kebebasan berkontrak. Salah satunya adalah prinsip itikad baik. Prinsip itikad baik harus lebih ditekankan lagi, mengingat prinsip ini dapat menjadi pengendali utama asas kebebasan berkontrak, karena sama-sama terdapat dalam Pasal $1338 \mathrm{BW}$, walau memang pada kenyataannya ada atau tidaknya prinsip itikad baik dalam sengketa kontrak, itu adalah kewenangan Hakim. The most direct challenge to the conception of contract law as a coherent expression of the principle of autonomy 
is thought to come from the doctrines of good faith, unconscionability, and duress. ${ }^{4}$

Mekanisme terakhir adalah yang harus diperhatikan manakala Pemerintah akan mewujudkan adanya undang-undang mengenai PPS sebagaimana di atas, yaitu sinergitas dengan undang-undang lain, seperti Undang-Undang Rumah Susun, UndangUndang Perlindungan Konsumen, atau UndangUndang Perumahan dan Pemukiman.

\section{PENUTUP}

\section{Kesimpulan}

Pre project selling merupakan suatu mekanisme penjualan yang cukup menjanjikan dewasa ini, dengan memanfaatkan asas kebebasan berkontrak dan norma lainnya dalam BW, perjanjian ini dapat lolos uji untuk keabsahannya. Guna mengikuti laju perkembangan bisnis dan efisiensi, perjanjian ini kerap dibuat oleh satu pihak saja, yaitu penjual, yang kemudian ditawarkan. Perjanjian ini kerapkali membawa kerugian pihak pembeli (calon pemilik), oleh karena itu diperlukan batasan atau pengendalian terhadap asas kebebasan berkontrak yang merupakan penopang utama bingkai bisnis seperti ini. Mekanismenya adalah dengan cara pembakuan perjanjian atau klausula perjanjian PPS, selain itu adalah dengan melibatkan Notaris, kemudian untuk normanya perlu ada sinergitas prinsip yang bernaung pada pasal yang sama (1338 BW), dan juga harus ada sinergitas dengan peraturan perundang-undangan lainnya.

\section{Rekomendasi}

Pemerintah perlu lebih peka dan bertindak untuk urgensi yang seperti ini, mengingat hal ini sebenarnya bukanlah hal yang baru untuk adanya kerugian yang diderita pihak pembeli (calon pemilik) pada peristiwa PPS. Pemerintah dengan kewenangannya diharapkan mampu memberikan jalan keluar baik itu melalui mekanisme di atas, ataupun melalui mekanisme lain. Semata-mata guna tetap memfasilitasi kegiatan bisnis dan perkembangannya.

\section{DAFTAR PUSTAKA}

\section{Buku:}

Burgerlijk Wetboek.

Charles Fries. (2015). Contract as Promise, A Theory of Contractual Obligation. Oxford: Oxford University Press.

\section{Jurnal:}

Dewi Hendrawati. (2011). "Penerapan Asas Kebebasan Berkontrak dalam Pembuatan Perjanjian Baku (Studi Normatif pada Perjanjian Pembiayaan Konsumen)". Jurnal MasalahMasalah Hukum. Jilid 40 No. 4 Oktober 2011. Semarang: Universitas Diponegoro.

Farid Husin. (2017). "Perjanjian Kerjasama Antara Pelaku Pembangunan Rumah Susun Dengan Bank Terhadap Penjualan Rumah Susun Melalui Sistem Pre Project Selling." Jurnal Spirit Pro Patria. Volume IV Nomor 1 Tahun 2017. Surabaya: Universitas Narotama.

Purbandari. (2012). "Kepastian dan Perlindungan

Hukum Pada Pemasaran Properti Dengan Sistem Pre Project Selling." Jurnal Widya. Tahun 29 Nomor 320 Mei 2012. Jakarta: Kopertis Wilayah 3.

\footnotetext{
${ }^{4}$ Charles Fries. (2015). Contract as Promise, A Theory of Contractual Obligation. Oxford: Oxford University Press, p. 74
} 